\title{
THE SUPPLY OF RIBONUCLEIC ACID TO THE MALE GERM CELLS DURING MEIOSIS IN ASELLUS AQUATICUS
}

\author{
G. MONTALENTI, G. VITAGLIANO and M. DE NICOLA \\ Department of Genetics, University of Naples
}

Received 14.v.49

\section{CONTENTS}

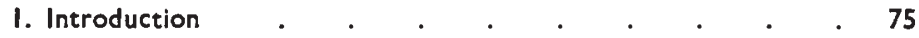

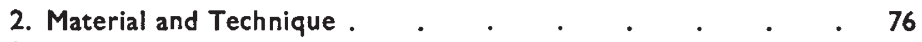

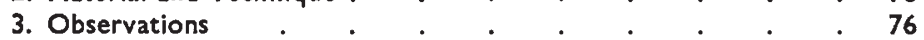

(a) The Structure of the Asellus testis . . . . . 76

(b) The Concordance between the Rhythm of Activity of the Follicular Cells and the Stage of Spermatogenesis . . 77

(c) Observations in vivo . . . . . . . . . 79

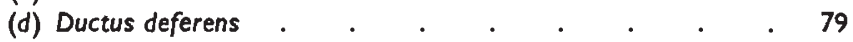



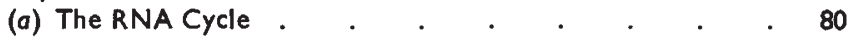

(b) The Secretory Process . . . . . . . . . . 81

5. Generalisation and Discussion . . . . . . . . 82

6. Summary . . . . . . . . . . . . . 84

7. References . . . . . . . . . . . . 85

\section{INTRODUCTION}

In the course of a study on the spermatogenesis of the isopod Asellus aquaticus L. (G. Montalenti and G. Vitagliano, I946 ; G. Vitagliano, 1947) attention was attracted to a layer of big secretory cells surrounding each testicular lobe or follicle. The large nuclei of these follicular cells are polyploid, similar to those described by Geitler (1939) in Gerris. Considerable variation in their structure was noticed. The variations were supposed to be correlated with endomitotic cycles. This hypothesis, however, had to be discarded because, if true, endomitosis would have been too frequent and the nuclei should have increased their volume indefinitely. This was not the case and a connection between the structure of nuclei and phase of physiological activity of the cells seemed more likely.

The older cytologists had long argued about the participation of nucleus in the secretory phenomena of the cell and it was realised that Asellus might be very favourable for a study of this problem. In fact, one of the most difficult questions, namely the correct seriation of the stages, could be easily cleared up if the secretion process bore some constant relation to the course of spermatogenesis. The latter, being almost synchronous in all the elements of each lobe, provides a time scale to which the phase of secretory activity of the follicular cells can be referred. 
A remarkable correlation between the structural aspect of follicular nuclei and the stage of spermatogenesis was found. At the same time it was realised that the secretion of the follicular cells is absorbed by the germ cells. Thus the problem shifted from secretion physiology towards the field of germ cell and meiosis physiology. The secretion was recognised as ribonucleic acid (RNA), which is presumably utilised in thymonucleic acid (DNA) synthesis during meiotic processes.

Preliminary reports of the essential results presented in this paper have already been published (G. Vitagliano, I948; M. de Nicola, I 948 ; G. Vitagliano and M. de Nicola, I948 ; G. Montalenti, I948). The original problem, i.e. the participation of the nucleus in secretory processes, will not be dealt with in full in the present paper.

\section{MATERIAL AND TECHNIQUE}

Testes of Arellus aquaticus L. (from the river Sarno, near Naples) were examined by the squash method or in sections. Squash preparations were made by the acetocarmine (Schneider) or acetoorcein (La Cour) methods, and occasionally restained by the Feulgen reaction, iron-hæmatoxylin or gentian violet. Material to be sectioned was fixed in Carnoy (acetic alcohol I : 3), Helly, Navashin, Flemming. Sections were stained with hæmatoxylin-eosin, iron-hæmatoxylin, Feulgen. The demonstration of ribonucleic acid was obtained by Unna-Pappenheim's stain with control by ribonuclease treatment, according to Brachet (I942). The demonstration of phosphatases was carried out by Gomori's technique (for technical details, $c f$. de Nicola, I948).

Control observations were made in living material with normal and polarised light.

\section{OBSERVATIONS}

\section{(a) The structure of the Asellus testis}

In the mid-dorsal region of the thorax of the male Asellus a pair of long slender tubes, the ducti deferentes, run towards their openings located in the ventral part of the seventh thoracic segment. Towards the opposite apical end three pear-like lobes or follicles are appended to each ductus deferens. In each of the six testicular lobes spermatogenesis takes place independently, but within each lobe the course of the germ cells evolution is fairly synchronous. In every follicle three main kinds of cells can be distinguished :-

(I) An investing layer of big follicular cells showing secretory activity and similar, although not identical, with the cells constituting the "neck" of the follicle and the epithelium of the deferens.

(2) The group of evolving spermatocytes (or spermatids, or fullyformed spermatozoa) which occupies the largest part of the follicular cavity. 
(3) A small group of spermatogonia, located somewhere towards the basal part of the follicle ; these are the source of the next spermatogenetic wave. When all the spermatocytes have been converted into spermatozoa, they are poured through the neck of the follicle into the ductus deferens.

(b) The concordance between the rhythm of activity of the follicular cells and the stages of spermatogenesis

As a preliminary observation it was found that two main " phases" exist in polyploid nuclei, viz. one characterised by large nuclear size, chromatin distributed in small blocks spaced within a non-staining nuclear sap, and the other characterised by smaller nuclear size and chromatin condensed in a mass in which the single blocks are not so easy to recognise. The former aspect is very similar to Gerris nuclei as described by Geitler (1939). The individual blocks may represent single chromosomes. No attempt was made to count them in order to ascertain the degree of ploidy, but apparently this is not very high, e.g. of the order of 8 to $\mathrm{I} 6$ ( $2 n=\mathrm{I} 6$ in Asellus).

By a more careful examination four "phases" were established and their correspondence with spermatogenetic stages thoroughly worked out by the study of some fifty sectioned testicular lobes and of a great number of squash preparations. The results of the observations are presented in the following table and in figs. I and 2.

A few words may be added to explain some points. In a testicular lobe full of spermatozoa the great majority of the follicular cells are in phase I. But in proximity to the group of spermatogonia, which are ready to start the next spermatogenetic wave as soon as the spermatozoa have been expelled, the follicular cells are in phase II.

Possibly two stages are included in phase II, the first with clearly visible threads, the second in which the aspect of the nucleus is more uniform. The interpretation is that the chromosomes (= chromatin blocks of phase I) are now threadlike, i.e. much less contracted and less charged with DNA. The whole chromatin structure is thus in a more diffuse condition.

Some additional nucleoli appear in phase II. One or two (which we consider identical with those of the other stages) are pyroninpositive and contain both kinds of phosphatases. Three to six additional nucleoli are devoid of RNA and of diphosphatases.

Phase III corresponds apparently to the stage of more intense secretion.

Phase IV is interpreted as a transitional stage to phase I.

The correspondence between spermatogenesis and follicle cell phase is such that in each spermatogenetic cycle phase I and IV appear only once, as the starting and final stage respectively, while phase II and III appear twice. There are thus two secretory waves with the maxima corresponding, one to lepto-zygotene, and the other to diakinesis-anaphase I. 
The secretion is constituted essentially by RNA (perhaps it is pure RNA) which, according to our observation, is absorbed and in some way utilised by the germ cells.

At the end of spermiohistogenesis no RNA is found between spermatozoa while the follicular cells have reached phase I, in which no secretory activity can be detected.

TABLE I

Follicular cells

\begin{tabular}{|c|c|c|c|}
\hline Phase & Nucleus & Nucleoli & Cytoplasm \\
\hline I & $\begin{array}{l}\text { Large, Chromatin in } \\
\text { small blocks of irregular } \\
\text { shape. No big chromo- } \\
\text { centers. Mp and Dp+ } \\
\text { on chromatin blocks. }\end{array}$ & $\begin{array}{l}\text { One or two, faintly } \\
\text { stained by pyronin.* }\end{array}$ & $\begin{array}{l}\text { Uniform, devoid of secre- } \\
\text { tion granules. Very } \\
\text { faintly stained by } \\
\text { pyronin. }\end{array}$ \\
\hline II & $\begin{array}{l}\text { Larger than in phase I. } \\
\text { Chromatin in diffused } \\
\text { condition. With aceto- } \\
\text { carmine and iron- } \\
\text { hæmatoxylin, a thread- } \\
\text { like structure appears } \\
\text { underneath the uniform } \\
\text { diffuse staining. } \\
\text { Mp reaction diffuse and } \\
\text { slight. } \\
\text { Dp-. }\end{array}$ & $\begin{array}{l}\text { Four to seven (with } \\
\text { iron - hæmatoxylin). } \\
\text { Only one or two are } \\
\text { stained by pyronin. } \\
\text { Mp+ in all nucleoli. } \\
\text { Dp+ in I-2 nucleoli, } \\
\text { in the others }- \text {. }\end{array}$ & $\begin{array}{l}\text { Vacuolar and full of small } \\
\text { granules, particularly } \\
\text { abundant around the } \\
\text { nuclear membrane. } \\
\text { The granules stain in- } \\
\text { tensely with pyronin. } \\
\text { Mp and Dp -. }\end{array}$ \\
\hline III & $\begin{array}{l}\text { Much contracted. No } \\
\text { granular structure } \\
\text { visible. } \\
\text { Granules, if existing, } \\
\text { closely packed in a } \\
\text { single mass. } \\
\text { Mp and } D p++.\end{array}$ & $\begin{array}{l}\text { One or two, intensely } \\
\text { stained by pyronin. } \\
\mathrm{Mp} \text { and } \mathrm{Dp}++\end{array}$ & $\begin{array}{l}\text { Filled with big granules } \\
\text { intensely stained by } \\
\text { pyronin. They are } \\
\text { expelled from the cell } \\
\text { and flow towards the } \\
\text { germ cells. Mp and } \mathrm{Dp} \\
\text { both absent from the } \\
\text { granules. }\end{array}$ \\
\hline IV & $\begin{array}{l}\text { Large. Chromatin in } \\
\text { blocks, less condensed } \\
\text { than in phase } 1 \text {. } \\
\mathrm{Mp} \text { and Dp }+ \text { on the } \\
\text { chromatin blocks. }\end{array}$ & $\begin{array}{l}\text { One or two, faintly } \\
\text { stained with pyronin. } \\
\mathrm{Mp} \text { and } \mathrm{Dp}+\text {. }\end{array}$ & $\begin{array}{l}\text { Alveolar containing a few } \\
\text { pyronin - positive } \\
\text { granules. } \\
\text { Mp and Dp - }\end{array}$ \\
\hline
\end{tabular}

* The staining by pyronin is given as a proof of the presence of RNA, since control with ribonuclease was done in every case. For the sake of brevity this is not stated every time. Concerning criticism on the specificity of the reaction, see Brachet and Shaver, 1948.

As to the distribution of phosphatases in the germ cells, the following can be noted. The cytoplasm and extracellular RNA granules are always negative. Spermatogonial nuclei are always strongly positive both for mono- and diphosphatases. The same is true of the spermatocytic nuclei, where it is easy to see that phosphatases closely follow the distribution of chromatin. In young spermatocytes these enzymes are localised in the tail region, as is the chromatin. The whole head of the spermatozoa is positive. 


\section{(c) Observations in vivo}

The diffused or condensed state of the chromatin can be detected also in vivo, although the details are of course much less clear. In polarised light the chromatin blocks of phases I and IV distinctly show birefringence, while in "diffuse" (phase III) nuclei no birefringence (cf. figs. I and 2).

Germ cells

\begin{tabular}{|c|c|c|c|}
\hline Stage & Intracellular space & Nucleus & Cytoplasm \\
\hline $\begin{array}{l}\text { Late spermatids } \\
\text { or fully formed } \\
\text { spermatozoa. }\end{array}$ & No granules of RNA. & $\begin{array}{l}\text { The distribution } \\
\text { of phosphatases } \\
\text { closely follows } \\
\text { the distribution } \\
\text { of chromatin. }\end{array}$ & $\cdots$ \\
\hline $\begin{array}{l}\text { Spermatogonia } \\
\text { and pachytene. }\end{array}$ & $\begin{array}{l}\text { Minute granules of RNA } \\
\text { are distributed among } \\
\text { the spermatogonia } \\
\text { which are ready to } \\
\text { initiate the next } \\
\text { spermatogenetic wave. } \\
\text { Practically no gran- } \\
\text { ules between sperma- } \\
\text { tocytes in pachytene. } \\
\text { Granules always de- } \\
\text { void of phosphatases. }\end{array}$ & $\begin{array}{l}\text { The distribution } \\
\text { of phosphatases } \\
\text { closely follows } \\
\text { the distribution } \\
\text { of chromatin. }\end{array}$ & $\begin{array}{l}\text { Staining pink with } \\
\text { pyronin in sperma- } \\
\text { togonia. Negative } \\
\text { to pyronin in } \\
\text { pachytene sperma- } \\
\text { tids. } \\
\text { Mp and Dp -. }\end{array}$ \\
\hline $\begin{array}{l}\text { Lepto - zygotene } \\
\text { and diakinesis } \\
\text { to anaphase I. }\end{array}$ & $\begin{array}{l}\text { Large amount of RNA } \\
\text { granules between } \\
\text { the spermatocytes. }\end{array}$ & $\begin{array}{l}\text { The distribution } \\
\text { of phosphatases } \\
\text { closely follows } \\
\text { the distribution } \\
\text { of chromatin. }\end{array}$ & $\begin{array}{l}\text { Strongly positive to } \\
\text { pyronin. } \\
\text { Mp and } D p-\text {. }\end{array}$ \\
\hline $\begin{array}{l}\text { Ana-telophase II } \\
\text { or young sper- } \\
\text { matids. }\end{array}$ & $\begin{array}{l}\text { RNA granules gradually } \\
\text { disappear. Groups of } \\
\text { young spermatids are } \\
\text { often oriented with } \\
\text { their tails towards } \\
\text { dumps of granules. }\end{array}$ & $\begin{array}{l}\text { The distribution } \\
\text { of phosphatases } \\
\text { closely follows } \\
\text { the distribution } \\
\text { of chromatin. }\end{array}$ & $\begin{array}{l}\text { Positivity to pyronin } \\
\text { gradually dis- } \\
\text { appearing. } \\
M p \text { and } \mathrm{Dp}-\text {. }\end{array}$ \\
\hline
\end{tabular}

++ means strongly positive Gomori reaction

+ pcsitive

- negative
Mp, monophosphatase Dp, diphosphatase

is observed. The same is true for the germ cells; when the chromatin is condensed (pachytene, metaphase, spermatozoa) a slight or strong (spermatozoa) birefringence is seen, which is lacking when the chromatin is in a "diffuse" condition (resting nuclei, prophase to pachytene).

\section{(d) Ductus deferens}

The epithelium of the ductus deferens is made up by elements similar to the follicular cells, although with a lower degree of polyploidy. 
Phases analogous to those found in follicular cells are evident also in the deferens cells, but they are more or less intermingled. Their secretion has not been carefully examined, but it is probably constituted by large granules staining red with pyronin, which are not deleter by ribonuclease. This substance, which also stains deeply with iron-hæmatoxylin, obviously is not RNA, and is found in large amounts between ripe spermatozoa.

\section{INTERPRETATION}

(a) The RNA cycle

From the observation cited above it follows that the function of follicular cells is to secrete considerable amounts of RNA which are expelled in the form of granules and supplied to the germ cells. These in turn absorb it as is demonstrated by the stainability with pyronin of the cytoplasm of spermatogonia and spermatocytes at definite stages. The feeding of RNA shows two maxima during each spermatogenetic cycle: viz. at the beginning of meiotic prophase and at diakinesis-metaphase I.

The results of the phosphatase reaction help us to ascertain where a metabolism of RNA occurs. Since it is highly probable that these enzymes are concerned with RNA metabolism (Brachet and Jeener, I946; Jeener, I947; Montalenti and de Nicola, I948) where phosphatases are absent there is probably no chemical elaboration of RNA. This happens during the whole migration of this substance, i.e. up to the cytoplasm of germ cells. Only in two points, viz. the starting point in follicular nucleus and the end point in germ cell nucleus, are the phosphatases present and in considerable amount. In other cells (e.g. other glandular cells, oocytes, etc.) in which RNA is present in cytoplasm, the phosphatases are also present in it. But here, according to the current views, RNA is in some way utilised for protein synthesis and thus presumably it undergoes change. Therefore the absence of phosphatases in the cytoplasm of both follicular and germ cells may indicate that it is carried through these bodies without any chemical modification.

The presence of phosphatases in nuclei, on the contrary, might indicate that there it is being metabolised. In follicular nuclei it is probably elaborated from the chromatin, whereas in germ cell nucleus it is eventually depolymerised into nucleotides which are used then to build up chromatin, i.e. DNA, according to the current view.

The supply of RNA to germ cells is thus considered as essential for completion of meiosis.

\section{(b) The secretory process}

As already stated the question of the participation of the nucleus in the secretory activity of the glandular cells has been long debated. Many older cytologists considered it very likely that the nucleus takes 
an active part in secretion. It lies outside the purpose of the present paper to review the literature concerning such a subject, but a few words may be added to interpret the phenomena described above.

In this particular case in which the cell secretes RNA it is clear that the nucleus is in some way concerned in the elaboration of this substance. This is shown by the considerable variations (I) of nuclear size, (2) of the state of condensation of chromatin and (3) of the number and size of nucleoli. All these features have already been described in a great variety of cells by many cytologists. Amongst recent papers Painter's (1945) work on the glandular cells of the bee and Drosophila is particularly exhaustive.

In the present case the phosphatase content of the nucleus throws some light on the process. The highest quantity of phosphatases is observed in phase III, in which other signs indicate that the secretory activity reaches its highest level. Furthermore the phosphatase reaction, as well as other staining methods, clearly show that in phase II there are at least two kinds of nucleoli. Their specific function is not known, but it seems highly probable that they are in some way concerned with some process in RNA elahoration.

As to whether eu- or heterochromatin is the source of RNA, our data do not allow of any conclusion. In mitotic chromosomes heterochromatin in Asellus does not form considerable blocks, but is interstitial in its distribution. We do not know whether the chromatin blocks which we consider as chromosomes in polyploid nuclei are entire chromosomes or merely heterochromatic bodies, as will perhaps be considered more probable.

At any rate the conclusion that RNA is elaborated in the nucleus at the expense or with the co-operation of the chromatin cannot be avoided.

\section{GENERALISATION AND DISCUSSION}

Were the case of Asellus isolated, its value would be purely episodic and no general conclusion could be drawn. But it seems more likely that such a fine mechanism of supply of nucleic acid to the male germ cells is at work also in other organisms. According to our interpretation it is essential for completion of meiosis.

A glance at the literature confirms this view. Brachet (1942) found progressive diminution of RNA content in the cytoplasm during spermatogenesis in the mouse, rabbit, grasshopper, and planarians. He did not describe a two-phase cycle as in Asellus, nor did he look for the source of RNA. Painter (1940) in the Rhoeo anthers finds the same diminution of RNA during the meiotic process. Moreover, he states that the tapetal cells contain a great amount of RNA in their cytoplasm. In the post-meiotic stage these cells cytolise and set free RNA, which accumulates in the pollen grain. The author states that " there is a similarity between microspore growth at the expense of tapetal cells and growth of oocytes in animals through the agency 
of nurse cells. Large amounts of ribonucleic acid are stored in mature pollen grain and used in the extremely rapid synthesis of new materials which accompanies pollen tube growth." He refers to his work (Painter and Reindorp, 1939) on the nurse cells of the ovary of Drosophila.

Oogenesis is a much more complex phenomenon than spermatogenesis : meiosis has a peculiar course owing to the cytoplasmic growth and elaboration and storage of yolk. The oocyte nucleus seems also directly concerned in supplying nucleic acids to the cytoplasm (Painter and Taylor, I940, 1942). Therefore this matter will not be dealt with here. But it seems possible that the tapetal cells in Rhoeo anthers give RNA to the microspore also in premeiotic and meiotic stages.

A "higher concentration in the cytoplasm of nucleic acid" in mother cells in comparison with their neighbours is found also by Darlington and La Cour (1946) in Fritillaria. Moreover, they describe temporary pre-prophase chromatin (DNA) dumps, not associated with chromosomes, which gradually shrink, contemporary with chromosome individuation, and eventually disappear at leptotene. The dumps are a source of DNA for the chromosomes which have to start meiosis. This case is, as far as is known, unique.

Many data from the older literature point to the presence in other animals of mechanisms similar to those in Asellus follicular cells. In almost any order of insects peculiar cells (Verson's cell, apical cell) have been described by several authors. Almost all of them agree in two points : viz. the cells elaborate a granular basophilic material (sometimes considered as chondriome) and this is fed to the germ cells. The latter are often seen in close connection with the apical cell, generally at an early (spermatogonial) stage and sometimes they send pseudopodium-like structures towards the apical cell. This has been interpreted as a " nurse cell" supplying "food" to the germ cells, and McClung (1938) even thought that in this way some impression or experience of the soma could reach the germ cells. A recent review of the literature on the apical cells in several insect orders is to be found in Carson (1945).

Whether the basophilic material excreted by the apical cells and absorbed by the germ cells is RNA remains, of course, to be demonstrated. It seems very probable and at least in one case, in grasshopper testis, it has been proved (B. Battaglia, in press).

Important observations were made by Holmgren (I9OI) in the testis of Staphylinus. First, the apical cell is not the only organ showing the secretory activity: the membrane of the single spermatogonial cysts also produces the same basophilic granules, and even the follicular capsule, syncytial in its structure, seems to have a high cytoplasmic basophily. Similar conditions have been found in grasshopper testes in "connective tissue cells." Probably this is the way by which a further amount of RNA is supplied to spermatocytes sometimes during 
the course of meiosis, as is in Asellus effected by the second climax of secretion.

A second and more important observation by Holmgren was that the size and shape of the apical cell, as well as of the whole follicular capsule varies very much according to the season and spermatogenetic stage. In winter, while spermatogenesis is in progress, both apical cell and capsule are thick and apparently very active. In spring, when meiotic stages come to their end and spermiohistogenesis starts, the apical cell is much smaller. In summer, when the testis is full of spermatozoa and devoid of spermatogonia and spermatocytes, Holmgren does not find the apical cell, and the capsule is reduced to an extremely thin layer. The activity of these secretory organs is therefore clearly connected with spermatogenesis as in Asellus.

Also in a Pteropode (Hyalocylis striata) the follicular cells surrounding the male section of the hermaphroditic gonad show a cycle of secretion of RNA, which is absorbed by the germ cells (Vitagliano and Bacci, unpublished).

In the vertebrates probably the Sertoli cells, in which Brachet finds a high content of RNA, have the same function.

There is no doubt that, looking more carefully into the literature and studying directly organisms of different types, it will be found that the supply of RNA to the male germ cells is provided for in a somewhat similar manner, although by different kinds of cells or cellular complexes. Research is in progress along this line in our laboratory.

The question may now be raised as to what is the causal relationship of this high charge of RNA supplied to the germ cells and the start and completion of meiosis. Darlington and La Cour (1946) have already stated that "what sets the series of changes (which will lead to crossing over, segregation and the whole course of meiosis) in motion seems to be the premature priming of the chromosomes with nucleic acid (premature with respect to their reproduction)." Modern research has demonstrated that meiosis is by no means confined to germ cells. Somatic cells are able to undergo more or less complete meiotic processes. In plants a number of cases have been described. E. Battaglia (1946) and E. Battaglia and Dolcher (I947) have carefully described incomplete and complete meiotic processes occurring in some glandular cells located at the basal part of the stilar canals in Sambucus. They did not look for RNA content in the cytoplasm of these cells, but two facts indicate that it should be rather high. First, the basophily of the cytoplasm, which is expressly described by the authors and appears also from the microphotograph accompanying their paper. Secondly, by the fact that Painter in Rhoeo found a considerable charge of RNA in the pistil, along the stilar canal. By analogy it may be supposed, while waiting for a demonstration, that this is true also in Sambucus.

In animals some cases of chromosomes pairing have been found in 
tumour cells, and particularly in those classified in category A by Santesson and Caspersson (1942), i.e. elements whose cytoplasm is heavily charged with RNA. Descriptions of such cases are to be found in Evans and Swezy (1929), Barigozzi and Cusmano (1946, 1947). Hearne (1936) and Hearne Creech (1940) found similar phenomena in mice fibroblasts cultivated in vitro and treated with carcinogenetic hydrocarbons.

A true "somatic reduction" has been described in polyploid cells of Culex (Berger, 1938 ; Grell, 1946). This process is very complicated and nothing is known about its determination or the RNA content of the cells concerned. Therefore this case cannot be taken into consideration for the moment.

From these data (and no doubt many more will be found in the literature) it appears that (a) RNA supply from the exterior to male germ cells immediately before and/or during meiosis should be a widespread feature among animals; $(b)$ somatic cells can undergo more or less complete meiotic processes; a common feature in the latter seems to be a heavy charge of RNA in the cytoplasm.

Therefore it may be supposed that a large amount of RNA is the cause, or at least one of the causes of the starting of meiosis. Possibly some enzyme might be bound to RNA and directly concerned in control of some meiotic process. Only experiment, of course, can give an answer. Some experimental data, however, are already at hand. Huskins ( $1948 a$ ) shortly reports that Kodani, by treating onion roots with sodium ribonucleate, obtained "chromosome pairing and reduction divisions, similar in essential respects to those of the germ cells." Similar cases have also been observed in material in which mitosis was induced by indole 3 acetic treatment. Apparently with sodium ribonucleate the number of reduction divisions is greatly increased.

In subsequent papers Huskins (1948b) and Wilson and Cheng (1949) describe their findings in Allium and Trillium roots following the treatment with sodium ribonucleate. They have obtained segregation of homologous chromosomes, but pairing "has been found so far in very few nuclei" (Huskins, 1948b).

Further observational and experimental data are required before any definite conclusion can be arrived at, but from this preliminary account it appears that the above-stated hypothesis is worth consideration.

\section{SUMMARY}

I. In the testis of Asellus aquaticus large follicular cells with polyploid nuclei are present. They are secretory elements, whose rhythmical work is in phase with the course of meiosis.

2. Follicular cells secrete ribonucleic acid (RNA) in granular form. During one spermatogenetic cycle the intensity of secretion shows two peaks: the first corresponding to lepto-zygotene, the 
second to diakinesis-metaphase I. Some features of the polyploid nuclei during the various phases of activity are shortly described.

3. The secretion given off from the follicular cells goes to the germ cells which absorb and utilise it as is demonstrated by the presence of RNA in their cytoplasm at certain stages, and its absence in other stages.

4. Phosphatase reaction shows that these enzymes are present in the follicular nuclei and germ cell nuclei, absent in the cytoplasm of both kinds of cells and on the RNA granules.

5. Therefore it is assumed that RNA is elaborated in polyploid nuclei and used in germ cell nuclei to build up chromatin (DNA).

6. Similar mechanisms of RNA supply to male germ cells seem quite widespread among animals. Thus the hypothesis is proposed and discussed that a heavy RNA charge, coming from outside the germ cell, is causally connected with the starting of meiosis.

\section{REFERENCES}

BARIGOZZI, C., AND GUSMANO, L. 1946.

Figure di appaiamento cromosomico in tessuti neoplastici umani.

Boll. Soc. Ital. Biol. Sperim., 22, 518-520.

BARIGOZZ1, G., AND CUSMANO, L. I 947.

Chromosome number in cancer cells.

Nature, 159,505 .

BAtTAGLiA, E. I 946 .

Divisione eterotipica in cellule somatiche di Sambucus ebulus L.

Nuovo Giorn. Bot. Ital., 54, I-9.

BATTAGLiA, E., AND DOLGHER, T. 1947.

Eumeiosi e meiosi apoomeotipica seguita da mitosi a diplounivalente nel tessuto somatico di Sambuco.

Nuovo Giorn. Bot. Ital., 53, I-9.

BERGER, G. A. $193^{8}$.

Multiplication and reduction of somatic chromosome groups as a regular development process in the mosquito Culex pipiens.

Carn. Inst. Washington, Publ. No. 496, 759-769.

BRAGHET, J. 1942.

La localisation des acides pentosenucléiques dans les tissus animaux et les oeufs d'Amphibiens en voie de développement.

Arch. de Biol., 53, 207-257.

BRAGHET, J., AND JEENER, R. I 946.

Phosphatases alcalines du noyaux et vitesse de remplacement du phosphore de l'acide thymonucléique.

C.R. Soc. Biol., I4O, I I $21-1122$.

BRACHET, J., AND SHAVER, J. R. 1948.

The effect of nucleases on cytochemical reactions for amino acids and on staining with acid dyes.

Stain Technol., 23, 177-181.

CARSON, H. L. I 945 .

A comparative study of the apical cell of the insect testis.

7. Morph., 77, I4I-I55. 
DARLington, C. D., AND LA COUR, L. F. 1946.

Nucleic acid and the beginning of meiosis.

Nature, $157,875-876$.

DE NICOLA, M. I948.

Distribuzione delle fosfatasi alcaline nei nuclei poliploidi delle cellule di rivestimento dei testicoli di Asellus aquaticus L.

Ric. Scient, 18, 1019-1022.

EVANS, H. M., AND SWEZY, O. 1929.

Mem. Univ. Calif., 9, I.

GEITLER, L. 1941 .

Das Wachstum des Zellkernes in tierischen und pflanzlichen Geweben.

Ergebn. d. Biol., I8, 1-54.

GRELL, S. M. I946.

Cytological studies in Culex. I. Somatic reduction divisions.

Genetics, 3I, 6o-86.

HEARNE, L. M. 1936.

Induced chiasma formation in somatic cells by carcinogenic hydrocarbons.

Nature, ${ }^{1}{ }^{8}$.

HEARNE CREECH, E. M. I 940 .

Carcinogenic and related non-carcinogenic hydrocarbons in tissue culture. I. and II. Amer. 7. Cancer, 35, 19I-202 ; 39, 149.

HOLMGREN, H. IgOI.

Über den Bau der Hoden und die Spermatogenesis von Staphilinus.

Anat. Anz., 19, 449-46r.

HUSKINS, C. L. $1948 a$.

Chromosome multiplication and reduction in somatic tissues.

Nature, $I 6$ I, 84-89.

HUSKINs, C. L. $1948 b$.

Segregation and reduction in somatic tissues. I. Initial observations on Allium cepa. J. Hered., 39, 310-325.

JEENER, R. 1947.

Sur les rapports existant entre la phosphatase alcaline et les nucléoproteines.

Actual. Biochim. (Masson, Paris ; Desoer, Liège), No. Io, 88-93.

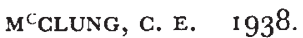

The apical cell of the insect testis. A possible function.

Trav. Stat. Zool. Wimereux, 13, 437-444.

MONTALENTI, G. 1948.

Considerazioni sul determinismo della meiosi.

Rend. Acc. Naz. Lincei., Serie VI., 5, 466-4.69.

MONTAlENTI, G., AND DE NicOlA, M. I948.

Distribuzione di fosfatasi alcaline in gonadi di Crostacei Isopodi in rapporto al ciclo degli acidi nucleici.

Experientia, 4, 315.

montalenti, G., and vitagliano, G. 1946.

Analisi della distribuzione dei chiasmi in Asellus aquaticus L.

Ric. Scient., I6, 944-948. 
PAINTER, T. S. I 940 .

Cell growth and nucleic acid in the pollen of Rhoeo discolor.

Bot. Gaz., ro5, 58-68.

PAINTER, T. S. I 945 .

Nuclear phenomena associated with secretion in certain gland cells with especial reference to the origin of cytoplasmic nucleic acid.

7. Exp. Zool., Ioo, 523-548.

PAINTER T. S., AND REINDORP, E. C. I939.

Endomitosis in the nurse cells of the ovary of Drosophila melanogaster.

Chromosoma., $1,276-283$.

PAINTER, T. S., AND TAYLOR, Q. N. I940.

Nuclear changes associated with the growth of oocytes in the toad.

Anat. Rec., Suppl. 78, 842.

PAINTER, T. S., AND TAYLOR, Q. N. I942.

Nucleic acid storage in the toad's egg.

Proc. Nat. Acad. Sci., 28, 3 I I-3 I 7.

SANTESSON, L., AND CASPERSSON, T. I 942.

Studies on protein metabolism in the cells of epithelial tumours.

Acta Radiol., Suppl. 46 .

VITAGLIANO, G. I 947 .

La spermatogenesi e la distribuzione dei chiasmi in Asellus aquaticus L.

Pubbl. Staz. Zool. di Napoli, 21, I64-1 82.

Vitagliano, G. I 948 .

Il metabolismo dell'acido ribonucleico nella spermatogenesi di Asellus aquaticus L.

Ric. Scient., I8, 840-843.

VITAGLiANO, G., AND DE NICOLA, M. I948.

Ribonucleic acid supply and phosphatase distribution during the spermatogenesis of Asellus aquaticus L.

Nature, r62, 965 .

WILSON, G. B., AND CHENG, K. C. I 949 .

Segregation and reduction in somatic tissues. II. The separation of homologous chromosomes in Trillium species.

7. Hered., $4^{\circ}, 3-6$. 
Fig. I.-Diagram showing the concordance between the rhythm of activity of the follicular cells (on the left) and the stage of the spermatogenesis (on the right). Further explanation, see table $\mathrm{I}$. 
Phase
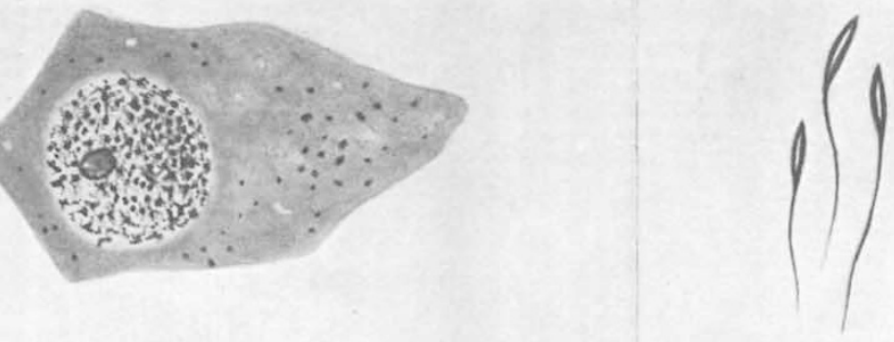

SPERMATOZOA
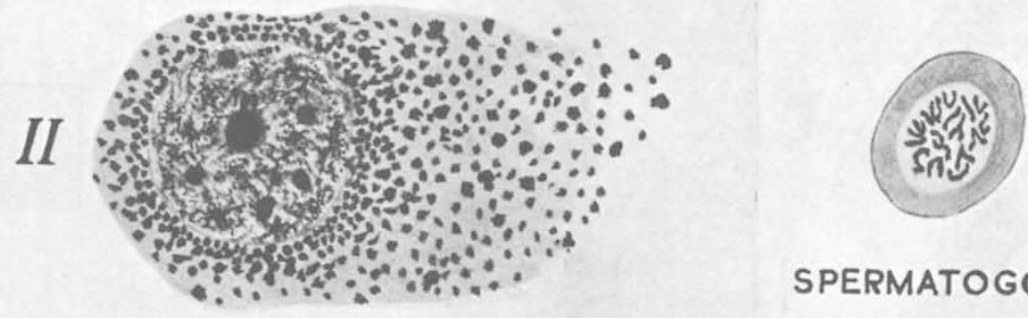

SPERMATOGONIA
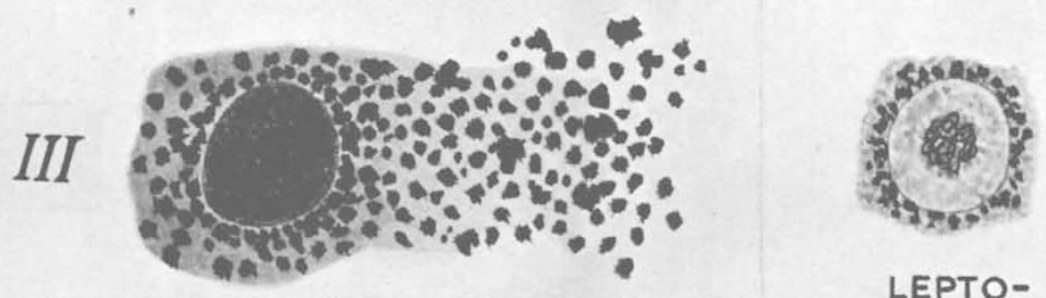

LEPTOZYGOTENE
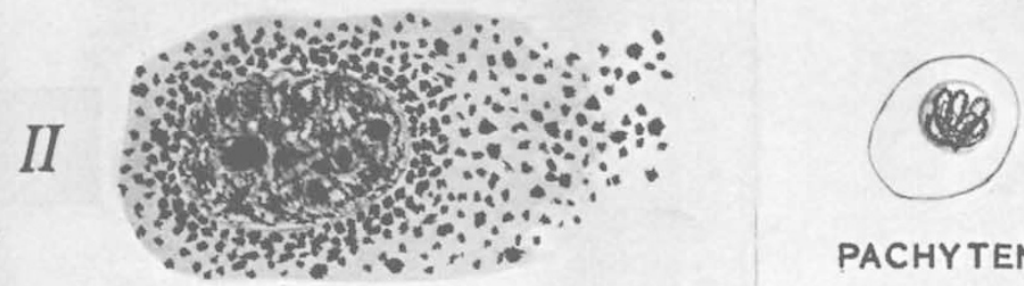

PACHYTENE
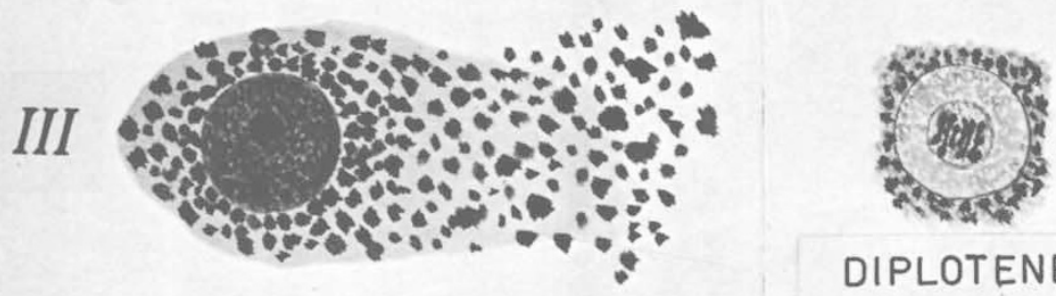

DIPLOTENEMETAPHASE I
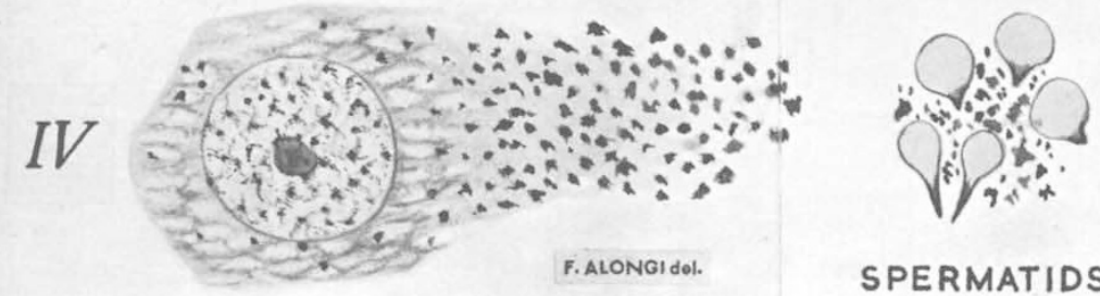


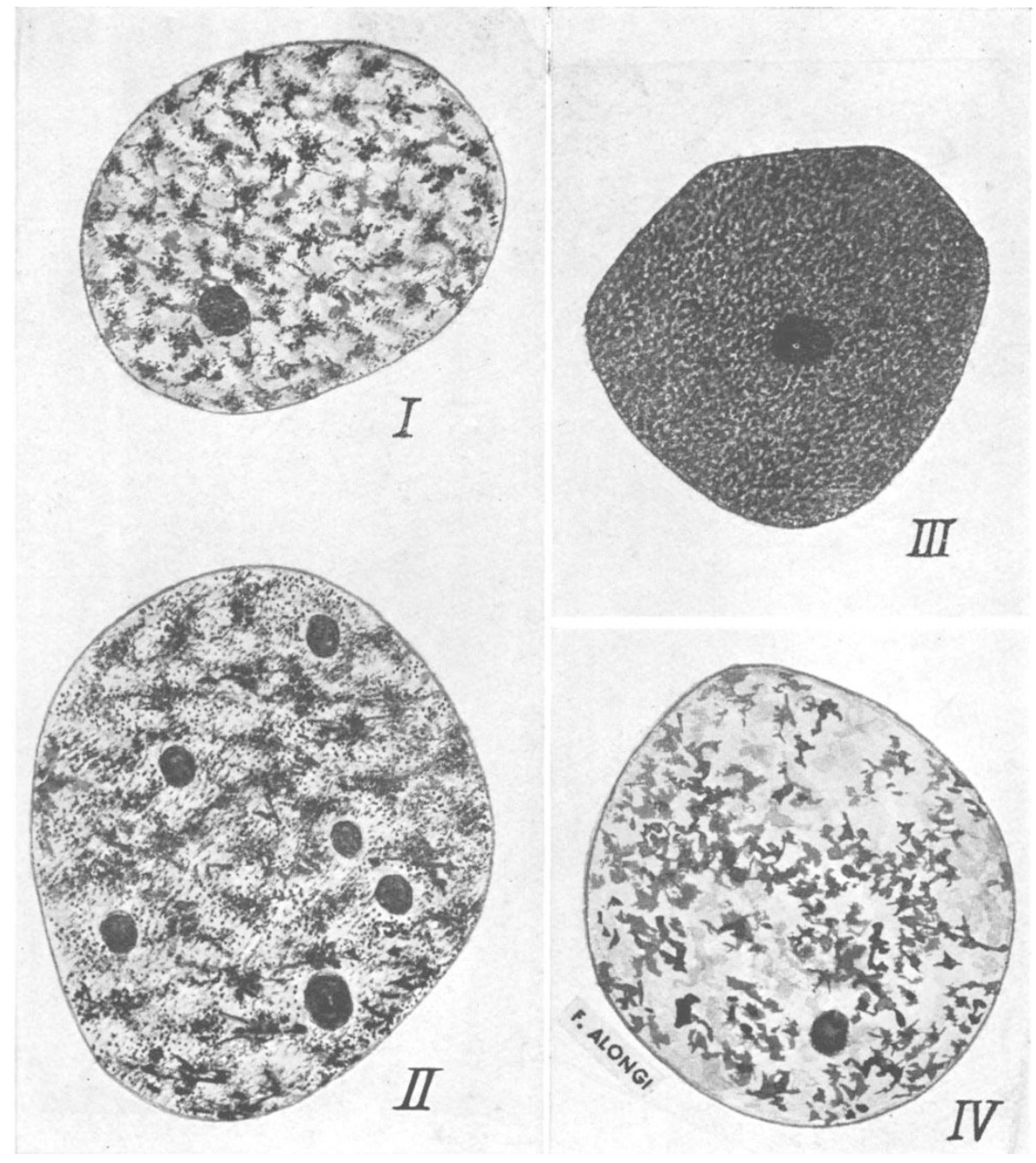

Frg. 2.-Nuclei of follicular cells corresponding to the phases indicated by the Roman figures below ( $c f$. table r). 